\title{
Effect Of Corn Straw Fermentation Time (Zea mays L) Using Aspergillus niger On Nutritional Concept
}

\author{
B. Dicky Kurniawan ${ }^{1}$, Sri Sukaryani ${ }^{2}$, and Engkus Ainul Yakin ${ }^{2}$ \\ ${ }^{1}$ Student of Program Study of Animal Science, Faculty of Agriculture, Universitas \\ Veteran Bangun Nusantara, Sukoharjo \\ ${ }^{2}$ Program Study of Animal Science, Faculty of Agriculture, Universitas Veteran \\ Bangun Nusantara, Sukoharjo \\ Corresponding author : engkus_ainul@yahoo.com
}

\begin{abstract}
This study aims to determine the optimal time of fermentation using Aspergillus niger on the $\mathrm{pH}$ value, dissolved protein and levels of ash content corn straw. The design used was a Completely Randomized Design (CRD) of unidirectional pattern consisting of 4 treatments repeated 3 times namely P0 : corn straw fermented with Aspergillus niger for 0 days, P1 : corn straw fermented with Aspergillus niger for 4 days, P2 : fermented corn straw with Aspergillus niger for 8 days, P3 : corn straw fermented with Aspergillus niger for 12 days. The parameters observed were $\mathrm{pH}$ value, dissolved protein and ash content. The results showed that corn straw fermented with Aspergillus niger had a very significant effect $(\mathrm{P}<0.01)$ on the $\mathrm{pH}$ value, dissolved protein content and ash content. Corn straw fermentation using Aspergillus niger for 0 12 days has a very significant effect on the $\mathrm{pH}$ value, dissolved protein content and ash content $(\mathrm{P}<0.01)$. The average $\mathrm{pH}$ value of the treatment $\mathrm{P} 0: 5,00, \mathrm{P} 1: 6,13, \mathrm{P} 2: 6,51$, P3: 6,84 The average value of dissolved protein content in the treatment P0: 27,09\%, P1: 33,31\%, P2: 24,14\%, P3: 25,51\%. The average value of ash content in the P0: $8,91 \%, \mathrm{P} 1: 11,34 \%, \mathrm{P} 2: 10,06 \%, \mathrm{P} 3: 9,22 \%$, As well as the optimal time achieved in fermentation for 4 days for dissolved protein content and ash content.
\end{abstract}

Keywords: Corn straw, Aspergillus niger, Fermentation, pH value, Dissolved protein content, Ash content

\section{Introduction}

Feed is anything that can be eaten by livestock, can be digested in whole or in part which is used to grow and develop. Feeding livestock needs to consider the amount, content and quality of nutrients in feed ingredients. The main animal feed needs are ruminants such as cattle consisting of fibrous feed with certain protein contents such as forage.

Corn straw is the remainder of the corn crop after the fruit is harvested minus the roots and some of the remaining stems and can be given to livestock, both fresh and dried. The use of corn straw is as ruminant animal feed such as cattle, buffalo, goats and sheep. Corn waste treatment is necessary for continuous feed continuity.

Nutrient quality in low corn straw such as high crude fiber content and low protein digestibility which can be overcome by feed processing technology is fermentation. Fermentation is a biological process that involves organic substrates through the enzyme activity of the activities of microorganisms. Microorganisms grow 
and develop actively changing fermented material into desired products in the fermentation process, the optimum fermentation process depends on the type of organism, one of which is a protein-producing microorganism is Aspergillus niger.

Aspergillus niger has an embodiment in the form of Proteolytic mold which is an enzyme producer that is able to change the change of insoluble protein into dissolved protein and can be digested in the body, but among farmers who have applied corn straw fermentation technology, it is still found different incubation time incubation, it is due to factors - the factors contained in the fermentation process so that this study is expected to be able to provide an overview of the fermentation time for the value of crude protein content and crude fiber in corn straw.

\section{Location}

\section{Materials and Methods}

This research was conducted at the Laboratory of the Faculty of Agriculture, Veterans University, Bangun Nusantara Sukoharjo, for 1 (one) month from April to May 2020.

\section{Materials}

Materials used in the study were Aspergillus niger, Molasses, Aquadest, Alcohol, PDA, Straw Substrate Corn which is chopper and dried.

The tools used in this research are: Plastic bucket, ose needle, $5 \mathrm{~kg}$ capacity digital scales, $500 \mathrm{ml}$ volume Erlenmeyer, Autoclave, Petri dish, Oven, Test tube, Micro pipette, Test tube rack, Plastic, Blender, $\mathrm{pH}$ Paper, Thermometer

\section{Experimental design}

This study was conducted with a corn straw fermentation experiment using Aspergillus niger with a completely randomized design (CRD) in a unidirectional pattern with 4 experiments. Each treatment was repeated 3 times to obtain 12 experimental units:

P0: Fermented Corn Straw with Aspergillus Niger for 0 days

P1: Fermented Corn Straw with Aspergillus Niger for 4 days

P2: Fermented Corn Straw with Aspergillus Niger for 8 days

P3: Fermented Straw Corn with Aspergillus Niger for 12 days

\section{Conducting research}

a. Microbial media preparation

Media used was PDA powder

b. Microbial preparation in the microbial used was Aspergillus niger

c. Microbial cultivation

Media made from PDA solutions and sterilized aquades then inoculated with Aspergillus nigerAspergillus niger in the test tube using theose. Media that have been planted with microbes are then put into an incubator for 7 days so that microbes develop.

d. Starter Making 
Prepare 500 grams of crushed corn straw, add 2\% drops of sugar cane and Aspergilus nigerand then cook for 7 days.

e. Fermentation

Enter Aspergillus niger into a bucket that has been filled with corn straw for microbial mixing every 500 grams of corn straw given $10 \mathrm{ml}$ of molasses and added 10 grams of starter, this experiment is carried out for 1 time treatment and divided into 3 experimental units. then the mixed straw corn starter is put into a jar and covered with mori cloth.

After the fermentation process is carried out, it is dried for 48 hours, then blended using a blender and filtered into flour powder.

\section{Variables observed}

a. $\mathrm{pH}$

Measurement of $\mathrm{pH}$ by wetting litmus paper ( $\mathrm{pH}$ meter) with corn straw that is still wet, then observed changes in color on litmus paper.

b. Dissolved Protein Levels of Dissolved Protein

Measurement as follows:

1. Samples from various treatments weighed as much as 1 gram

2. Samples that had been weighed were put in an erlenmeyer dissolved using 100 $\mathrm{ml}$ of distilled water and put into a measuring flask,

3. Take the solution as much as $1 \mathrm{ml}$ put into a test tube

4. Add reagents D $1 \mathrm{ml}$ of vortex until dissolved and let stand for 15 minutes,

5. After 15 minutes add back reagent $E$ as much as $3 \mathrm{ml}$ then vortex back and let stand for 45 minutes,

6. After 45 minutes, measure using a spectro with $540 \mathrm{~nm}$ wavelength

c. Ash Levels follows:

The procedure for measuring Ash Levels by dry ashing (AOAC, 1995) is as

1. Prepare the crucible then the oven for 15 minutes

2. Remove the crucible from the oven then put it into the desiccator one by one using tongs and leave it for 15 minutes

3. Remove Crush from the desiccator and weigh the sample into a crucible that has been known to weigh as much as 1 gram.

4. Heat the sample to be crushed into the furnace at $500^{\circ} \mathrm{C}$ and finally incandescent to total ash.

5. After being ash the sample is cooled into a desiccator for 30 minutes, then weighed to a constant weight.

\section{Results And Discussion}

This study aims to determine the increase in acidity, dissolved protein content and ash content in fermented corn straw with different fermentation times, namely $0,4,8$, 12 days. Increasing the acidity, in corn straw fermented with Aspergillus niger can be seen in Table 3. Then the average fermentation results with Aspergillus niger on the content of dissolved protein can be seen in Table 4 . Then the average fermentation results with Aspergillus niger on the ash content can be seen in Table 5. 


\section{pH (Degree of Acidity)}

Based on Table 1 shows the results of the fermentation anova test using Aspergillus niger have a very significant effect on the $\mathrm{pH}$ value of corn straw $(\mathrm{P}<0.01)$, followed by duncan tests which showed differences between treatments.

Table 1. The Effect of Long Time fermentation of Corn Straw Using Aspergillus niger on The Degree of Acidity $(\mathrm{pH})$

\begin{tabular}{ccccc}
\hline Deuteronomy & \multicolumn{4}{c}{ Treatment } \\
\cline { 2 - 5 } & P0 & P1 & P2 & P3 \\
\hline 1 & 5.00 & 6.40 & 6.67 & 6.84 \\
2 & 5.00 & 5.80 & 6.44 & 6.92 \\
3 & 5.00 & 6.20 & 6.44 & 6.77 \\
\hline Average & $5.00^{\mathrm{a}}$ & $6.13^{\mathrm{b}}$ & $6.51^{\mathrm{c}}$ & $6.84^{\mathrm{d}}$ \\
\hline
\end{tabular}

Remarks ${ }^{\mathrm{a}, \mathrm{b}, \mathrm{c}, \mathrm{d}}:$ Different superscripts on the same line show very significant differences $(\mathrm{P}<0.01)$

Based on table 1 shows the increase in $\mathrm{pH}$ in each treatment due to fermentation with the use ofmushrooms Aspergillus niger done Aerobically this causes the substrate to be exposed to oxygen for too long, this is in accordance with Tabbaco et al., (2011) states that the high $\mathrm{pH}$ can be triggered by exposure to silage for too long, causing aerobic fermentation to occur again. The high $\mathrm{pH}$ value is also influenced by the low protein content of corn straw. according to Despal et al., (2011) Low plant protein content causes low buffering capacity so that acidification is easier.

\section{Dissolved Protein Levels}

Table 2. The Effect of Long Time fermentation of Corn Straw Using Aspergillus niger on The Dissolved Protein Levels (\%)

\begin{tabular}{ccccc}
\hline Deuteronomy & \multicolumn{4}{c}{ Treatment } \\
\cline { 2 - 5 } & P0 & P1 & P2 & P3 \\
\hline 1 & 24.88 & 36.58 & 23.78 & 28.18 \\
2 & 28.58 & 31.88 & 24.88 & 25.98 \\
3 & 27.81 & 31.48 & 23.78 & 22.38 \\
\hline Average & $27.09^{\mathrm{a}}$ & $33.31^{\mathrm{b}}$ & $24.14^{\mathrm{a}}$ & $25.51^{\mathrm{a}}$ \\
\hline
\end{tabular}

Remarks $^{\mathrm{a}, \mathrm{b}}$ : Different superscripts on the same line show very significant differences $(\mathrm{P}<0.01)$

Based on Table 2 shows the results of anova fermentation test using Aspergillus niger have a very significant effect on the dissolved protein content of corn straw ( $\mathrm{P}$ $<0.01)$, followed by the duncan test that at the P0 treatment $(27.09 \%)$ day $0, \mathrm{P} 2$ (P2 $24.14 \%)$ on the 8th day and on the P3 $(25.51 \%)$ treatment on 12 day showed results that were not significantly different from the lower results than P1 (33.31\%), this is because 
thefungus Aspergillus niger was already in phase stationary (slowing down) where the amount of food has thinned so that the decline in mass and concentration of mold mycelium on corn straw substrate in accordance with this according to Fardianz (1922) in Setyawati et al. (2013) The pattern of microbial growth is initially slow (phase phases lag), because of the effort to adapt to the environment, then grow fast (log phase), i.e. when abundant food, then it will slow down and stationary (stationary phase), which occurs when food conditions in the substrate thin out, then dian growth decreases and leads to death (dead phase), which occurs when the nutrients in the substrata or medium needed are exhausted.

P1 treatment $(33.31 \%)$ showed the highest average yield, this is because Aspergillus niger experienced a peak growth phase on day 4, resulting in increased mass and concentration of mold mycelium on corn straw substrate. So it can be said that the fermentation of Aspergillus niger on day 4 can increase levels of dissolved protein in accordance with Indriyanti, (2013) in Angraini (2018) The increase in protein is caused by protein synthesis by a mold consortium. Besides the increase in protein is also due to an increase in mold mycelium on the substrate. This is because mold itself contains nucleic acids which can contribute to nitrogen which is a source of single cell protein.

\section{Ash Content}

Table 3. The Effect of Long Time fermentation of Corn Straw Using Aspergillus niger on The Ash Levels (\%)

\begin{tabular}{ccccc}
\hline Deuteronomy & \multicolumn{4}{c}{ Treatment } \\
\cline { 2 - 5 } & P0 & P1 & P2 & P3 \\
\hline 1 & 8,59 & 12,33 & 10,73 & 10,08 \\
2 & 9,34 & 10,75 & 9,77 & 8,64 \\
3 & 8,81 & 10,95 & 9,67 & 8,93 \\
\hline Average & $8,91^{\mathrm{a}}$ & $11,34^{\mathrm{b}}$ & $10,06^{\mathrm{a}}$ & $9,22^{\mathrm{a}}$ \\
\hline
\end{tabular}

Remarks ${ }^{\mathrm{a}, \mathrm{b}}:$ Different superscripts on the same line show very significant differences $(\mathrm{P}<0.01)$

Based on Table 3 shows the results of anova fermentation test using Aspergillus niger have a very significant effect on the ash content of corn straw $(\mathrm{P}<0.01)$, followed by duncan test that at treatment P0 $(8.91 \%)$ on days $0, \mathrm{P} 2(10,06 \%)$ on the 8 th day and on the treatment of P3 (9.22\%) the 12th day showed no significant difference with the results lower than P1 (11.34\%), this is because the growth of Aspergillus niger began to decline and food in the substrate thinning has entered the stationary phase (slowing down), according to Caroline et al ,. (2015) Aspergillus niger experienced an exponential phase and reached a peak of growth at the 120th hour, followed by a decrease in dry weight of the cells which signified entering the death phase at the 144th hour.

The treatment on P1 (11.34\%) showed the highest yield due to the treatment of P1 for a long fermentation period of 4 days Aspergillus niger had successfully adapted and got abundant food and grew rapidly (log phase), causing an increase in the number offungi Aspergillus niger growing and increasing levels of straw ash ash, according to 
Winarno, (1992) in Purwanti, (2012) The increase in ash content was also due to the large number of mold mycelium and increased protein.

\section{Conclusion}

This research can be concluded that the fermentation of corn straw using the fungus Aspergillus niger for 0 - 12 days has a very significant effect on the $\mathrm{pH}$ value, dissolved protein content and ash content.

\section{Reference}

Carolina A, Sidik A, Maksum I. P, Rachman S.D, Safari A dan Ismayana, S. 2015. Fermentasi Biak Rendam Molases Dengan Aspergillus Niger Untuk Produksi Asam Sitrat. Chimica et Natura Acta . 3(1) : 25-29

Despal, I. G. Permana, S. N. Safarina, \& A. J. Tatra. 2011. Penggunaan berbagai sumber karbohidrat terlarut air untuk meningkatkan kualitas silase daun rami. MediaPeternakan. 67-69

Fardiaz, S. 1992. Mikrobiologi Pangan I. Jakarta : PAU Pangan dan Gizi IPB. Bogor bekerja sama dengan P.T. Gramedia Pustaka Utama.

Irawati, 2008.Modul Pengujian Mutu. I. Diploma IV PDPPTK Vedca, Cianjur.

Purwanti, F. W. 2012. Kualitas Nutrien Onggok Yang Difermentasi Aspergillus Niger Dengan Penambahan Level Urea dan Zeorit Yang Berbeda.Skripsi. Fakultas Peternakan Institut Pertanian Bogor, Bogor.,

Purwoko, Tjahjadi Dan Noor Soesanti Handajani. 2006. "Kandungan Protein Total Dan Terlarut Kecap Manis Tanpa Fermentasi Moromi Hasil Fermentasi R. oryzae Dan R.oligosporus". Penelitian Dosen Muda.Surakarta: Universitas Sebelas Maret.

Tabacco, E., F. Righi, A. Quarantelli, \& G. Borreani. 2011.Dry matter and nutritional losses during aerobic deterioration of corn and sorghum silages as influences by different lactic acid bacteria inoculan. J. Dairy. Sci. 94:1409-1419.

Winarno, F. G. 1986. Kimia Pangan dan Gizi. Jakarta. Gramedia Pustaka Utama. 